\title{
POST-DIVORCE MATRIMONIAL PROPERTY DISTRIBUTION: A CASE STUDY OF POLYGAMY MARRIAGE
}

\author{
Muhammad Kamran \\ Magister Student of Legal Studies Program, Universitas Muslim Indonesia, Makassar \\ Email Correspondence: muhammadkamran030196@gmail.com
}

Date of Submission: May 6, 2020

Date of Publication: June 3, 2020

\begin{abstract}
This research aims to determine and understand what factors influence the effectiveness of post-divorce matrimonial property distribution in a case study of polygamy marriage in the Religious Court of Class 1A Makassar. This type of research is socio legal study research, and was conducted in Makassar City. The results showed that the effectiveness of post-divorce matrimonial property distribution in a case study of polygamy marriage in the Religious Courts of Class 1A Makassar can be seen based on five factors, including legal factors, law enforcement factors, facility factors, community factors, and cultural factors. Data obtained from all factors showed less effective results, including there, were $65 \%$ claims to legal factors, $72.5 \%$ claims to law enforcement factors, $60 \%$ claims to facility factors, $61.25 \%$ claims to community factors, and $62.5 \%$ claims to cultural factors. Seriousness is needed, especially for law enforcement in carrying out their role, and it is hoped that all relevant stakeholders must socialize the rules regarding procedures for the post-divorce matrimonial property distribution.
\end{abstract}

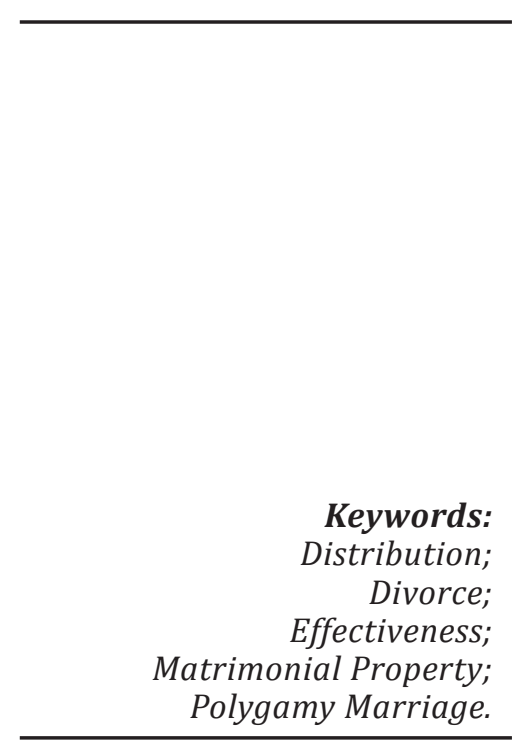

Articles with open access under a CC BY SA-4.0 license

\section{INTRODUCTION}

Based on Article 1 Law of the Republic of Indonesia Number 16 of 2019 on Amendment to Law Number 1 of 1974 on Marriage (hereinafter referred to as Law No. 16 of 2019) means that: ${ }^{1}$

"Marriage is an inner bond between man and woman as husband and wife with the aim of forming a happy and lasting family (household) based on Belief in the one and only God."

Furthermore, based on Article 3 section (1) Law No. 16 of 2019 regulates that "in principle, in a marriage a man can only have a wife. A woman can only have a husband."

From the above provisions, marriage in Indonesia is based on the principle of monogamy, but that principle is not absolute. This is because it is based on Article

${ }^{1}$ Lihat juga Zunaidi, Arif. (2018). Kedudukan Harta Bersama Perkawinan Poligami. Mahakim: Journal of Islamic Family Law, Institut Agama Islam Negeri Kediri, 2(2), p. 91.

DOI: https://doi.org/10.37276/sijl.v2i2.29 
3 section (2) Law No. 16 of 2019 regulates that "The court can give permission to the husband to have more than one wife if desired by the relevant parties." juncto Article 4 section (1) Law No. 16 of 2019 regulates that "In the event that a husband will have more than one wife, ... then he is required to submit an application to the Court in his area of residence." juncto Article 5 section (1) Law No. 16 of 2019 regulates that in order to submit an application to the Court, ... must meet the requirements as follows:

a. there is agreement from the wife/wives;

b. there is the certainty that husbands can guarantee the necessities of life for their wives and children;

c. there is a guarantee that the husband will be fair to their wives and children.

From the above provisions, it can be concluded that marriage in Indonesia is expected to be monogamous, making it difficult for husbands to submit applications for polygamy, but not with the aim of eliminating the application of polygamy for the people in Indonesia. ${ }^{2}$

The community must be more aware and understand that polygamy in Islam is an act that is in an emergency. That is, the action of polygamy will not be carried out and applies as long as the husband's household conditions are in good condition and even show harmony. ${ }^{3}$

Polygamy marriage is Islamic law and will last until the end of time. Polygamy is permitted in conditions that if a husband has more than one wife, it is obligatory for him to be fair among them, by giving the same life, giving clothes, residence, and time to spend the night together. ${ }^{4}$ This condition is also known and understood in QS. An-Nisa' verse (3), that:

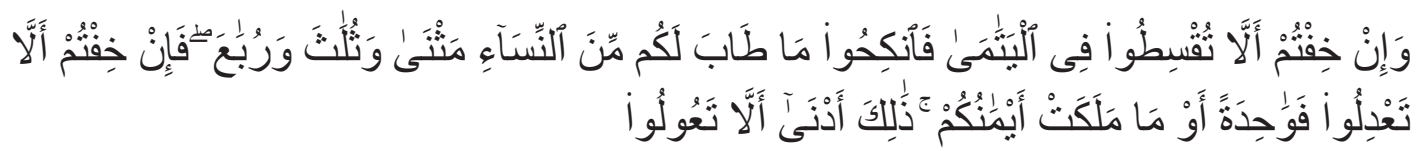

"And if ye fear that ye will not deal fairly by the orphans, marry of the women, who seem good to you, two or three or four; and if ye fear that ye cannot do justice (to so many) then one (only) or (the captives) that your right hands possess. Thus it is more likely that ye will not do injustice."

On the other hand, marriage is a very important legal event in the life of the Indonesian people. The legal consequences of marriage are not only related to the legal relationship between the prospective husband and wife, but also with parents from both parties, brothers and sisters, and even the families of both parties. At the time of marriage, couples looking for income to meet their needs. From this income also present Matrimonial Properties. Matrimonial property can be in the form of assets obtained by a wife or husband during marriage.

\footnotetext{
${ }^{2}$ Alaidrus, Mochammad Soleh. (2009). Pelaksanaan Pembagian Harta Perkawinan dalam Perkawinan Poligami (Studi di Pengadilan Agama Bekasi). Notarius, Universitas Diponegoro, 1(1), p. 1.

${ }^{3}$ Hasan, M. Ali. (2003). Pedoman Hidup Berumah Tangga dalam Islam. Jakarta: Kencana Prenada Media Group, p. 269.

${ }^{4}$ As-Sanan, Arij Abdurrahman. (2003). Memahami Keadilan dalam Poligami (Ahmad Sahal Hasan, Trans.). Jakarta: PT. Globalmedia Cipta Publishing, p. 25.
} 
Based on Article 35 section (1) Law No. 16 of 2019 regulates that "Property obtained during marriage becomes matrimonial property" juncto Article 1 point f Presidential Instruction of the Republic of Indonesia Number 1 of 1991 on Spread of Compilation of Islamic Law (hereinafter referred to as Inpres No. 1 of 1991) means that:

"Property in marriage or Syirkah is property obtained either individually or by husband and wife during a marriage, hereinafter referred to as matrimonial property, without questioning being registered in the name of anyone."

From the above provisions, it can be seen that the existence of matrimonial property in a marriage is from the time of marriage until the date of the marriage bond ends.

Furthermore, based on Article 38 Law No. 16 of 2019 regulates that marriage can end because:
a. death;
b. divorce; dan
c. on the court's decision.

From the above provisions have legal consequences, that the termination of marital relations often presents disputes that have legal effects that affect the rights and obligations between ex-husband and ex-wife and children born from the marriage. Likewise, matrimonial property obtained during the marriage bond takes place and private property before each marital marriage.

On the other hand, based on legal facts, especially in the divorce process in polygamy marriage in the Religious Court of Class 1A Makassar, a problem that is often found is that the husband smuggled the rights of his previous wife. Because of this legal fact, in addition to the problem of distribution and separation of matrimonial property, it is important to address and reveal more deeply about what factors influence the effectiveness of post-divorce matrimonial property distribution in a case study of polygamy marriage.

Based on the description above, the purpose of this study is to find out and understand what factors influence the effectiveness of post-divorce matrimonial property distribution in a case study of polygamy marriage in the Religious Courts of Class 1A Makassar.

\section{METHOD}

This type of research is socio legal study research. ${ }^{5}$ This research was conducted in Makassar City and consisted of several locations, including in the Religious Courts of Class 1A Makassar, Advocate Office, Notary Office, and settlement of Religious Figures. Determination of respondents as research populations based on their characteristics, including 15 respondents from Judges of the Religious Courts of Class 1A Makassar; 10 respondents from Clerk of the Religious Courts of Class 1A Makassar; 10 respondents

\footnotetext{
${ }^{5}$ Rahman, Sufirman, Qamar, Nurul, \& Kamran, Muhammad. (2020). Efektivitas Pembagian Harta Bersama Pasca Perceraian: Studi Kasus Perkawinan Poligami. SIGn Jurnal Hukum, CV. Social Politic Genius (SIGn), 1(2), p. 107.
} 
from Clerk of the Religious Courts of Class 1A Makassar; 5 (five) Respondents from Bailiffs of the Religious Courts of Class 1A Makassar; 30 Respondents from Advocates; 5 (five) Respondents from Religious Figures; and 10 respondents from the community who have been through the court process. Furthermore, the types and sources of data include primary and secondary data, where primary data is obtained directly at the study site through an interview process, while secondary data is obtained from research results using library materials such as Books, Scientific Journals, Scientific Articles, Professor Inauguration Speeches, Thesis, Legislation, official documents and other writings that have relevance to the discussion of this research. The results of this study were obtained from a qualitative analysis based on respondents' questionnaires and presented in the form of frequency tabulation and percentage distribution.

\section{RESULTS AND DISCUSSION}

Marriage is a sacred covenant between men and women in forming a family. ${ }^{6}$ marriage is a very important legal event in the life of the Indonesian people. This is because marriage is not only related to the legal relationship between the prospective husband and wife, but also with parents from both parties, brothers and sisters, and even the families of both parties.

Marriage based on Islam is worship, holding a marriage is also part of perfecting half of its religion. Marriage aims to grow a family consisting of mutual love and affection between family members. ${ }^{7}$

One practice of marriage is polygamy marriage. In the legal aspects of polygamy marriage, of course, there are several consequences, including the rights and obligations of husband and wife and matrimonial property in marriage. ${ }^{8}$

Based on the normative and empirical point of view or das sollen and das sein, implementation of post-divorce matrimonial property distribution in a case study of polygamy marriage is influenced by several factors. On the other hand, marriages regulated in Law No. 16 of 2019 and Inpres No. 1 of 1991, contains provisions that make divorce difficult. However, that does not rule out the possibility that a marriage that begins with love and affection will be forever harmonious. A good settlement is needed if there is a fight in the household, so divorce can be avoided. Some divorce incidents are caused by simple problems, such as domestic fights that cause disharmony, incompatibility, or mistrust between husband and wife. From divorce events, often between husband and wife questioning property in marriage, especially matrimonial property distribution.

\footnotetext{
${ }^{6}$ Yunus, Ahyuni. (2020). Hukum Perkawinan dan Itsbat Nikah: Antara Perlindungan dan Kepastian Hukum. Makassar: Humanities Genius, p. 27.

${ }^{7}$ Dahwal, Sirman. (2017). Perbandingan Hukum Perkawinan. Bandung: CV. Mandar Maju, p. 17.

${ }^{8}$ Fitrianti, Desi. (2017). Harta Bersama dalam Perkawinan Poligami Menurut Undang-Undang Nomor 1 Tahun 1974 dan Hukum Islam. Jurnal Intelektualita: Keislaman, Sosial dan Sains, Universitas Islam Negeri Raden Fatah Palembang, 6(1), p. 89.
} 
As explained in the introduction where based on Article 38 Law No. 16 of 2019 regulates that marriage can end because: ${ }^{9}$

a. death;

b. divorce; dan

c. on the court's decision.

When looking at the current legal reality, the post-divorce problem which also still causes many pros (responding good or positive) and cons (responding poorly or negatively), is identifying what factors influence the effectiveness of post-divorce matrimonial property distribution in a case study of polygamy marriage. The effectiveness of the law can be interpreted that: ${ }^{10}$

"First of all, it must be able to assess the extent to which the rule of law is obeyed or not obeyed by the community. If the rule of law is obeyed by most people, it can be said that the rule of law is effective."

Effectiveness comes from the effective word which means how to achieve the goal by choosing the correct way from several alternatives, then applying it based on the specified time. Effectiveness is always related to the relationship between expected results and the results that have been achieved. Effectiveness is the ability to carry out tasks in an organization, without pressure or tension from any party. So the effectiveness of law according to the above understanding is the ability to perform tasks in an organization by choosing the correct way from several alternatives so that the results achieved are as expected. ${ }^{11}$ Furthermore, the effectiveness of legislation can be determined by five factors, namely: ${ }^{12}$

1. Legal factors (regulations in the form of norms/legal norms);

2. Law enforcement factors (making or application of the law);

3. Facility factors (support law enforcement);

4. Community factors (environment/place of application of the law);

5. Cultural factors (the norms of indigenous peoples who are still alive and wellmaintained).

The five factors above integratively and systematically will determine the effectiveness of law in society. In accordance with the theory of sociological jurisprudence that " $A$ good law is a law that is in accordance with the law that lives in society. In accordance here means that the law reflects the values that live in society". ${ }^{13}$

\footnotetext{
${ }^{9}$ Vide Alexander, Ongky. (2019). Efektivitas Pembagian Harta Gono - Gini Pasca Perceraian dalam Persfektif Yuridis Sosiologis. El-Ghiroh: Jurnal Studi Keislaman, Sekolah Tinggi Agama Islam Bumi Silampari, 16(1), pp. $120-121$.

${ }^{10}$ S., Salim H. \& Nurbani, Erlies Septiana. (2013). Penerapan Teori Hukum pada Penelitian Tesis dan Disertasi. Jakarta: PT. Raja Grafindo Persada, p. 375.

${ }^{11}$ Siregar, Nur Fitryani. (2018). Efektivitas Hukum. Al-Razi:Jurnal Ilmu Pengetahuan dan Kemasyarakatan, Sekolah Tinggi Agama Islam Barumun Raya, 18(2), pp. 2 - 3.

${ }^{12}$ Soekanto, Soerjono. (2016). Faktor-Faktor yang Mempengaruhi Penegakan Hukum. Jakarta: PT. Raja Grafindo Persada, p. 8.

${ }^{13}$ S., Salim H. \& Nurbani, Erlies Septiana. (2013). Op. Cit., p. 32.
} 
From the theory of sociological jurisprudence, the effectiveness of norms is determined by the level of community compliance with the law, including law enforcement. There is a very familiar phrase, that: ${ }^{14}$

"A high level of compliance is an indicator of the functioning of the legal system, and the functioning of the law is an indicator that the law achieves legal objectives that seek to defend and protect all citizens."

Based on research that has been conducted relating to the factors that influence the effectiveness of post-divorce matrimonial property distribution in a case study of polygamy marriage in the Religious Courts of Class 1A Makassar, the five factors will be explained one by one, including the following:

\section{A. Legal Factors}

The results of the data obtained from the interview process with respondents about the effectiveness of post-divorce matrimonial property distribution in a case study of polygamy marriage based on legal factors can be seen in the table below.

Table 1. Effect of Legal Factors

\begin{tabular}{c|l|c|c}
\hline \hline No. & Statement/Category & Frequency & Percentage \\
\hline \hline 1. & Effective & 28 & $35,00 \%$ \\
\hline 2. & Less Effective & 52 & $65,00 \%$ \\
\hline 3. & Ineffective & 0 & $0,00 \%$ \\
\hline \hline \multicolumn{2}{r|}{ Total } & $\mathbf{8 0}$ & $\mathbf{1 0 0 \%}$ \\
\hline \hline
\end{tabular}

Source: Questionnaire Results of 2019 - 2020

From the table above it can be seen that there are 28 respondents or $35,00 \%$ claims effective, 52 respondents or $65,00 \%$ claims less effective, and no respondent claim ineffective. It can be judged that the effectiveness of post-divorce matrimonial property distribution in a case study of polygamy marriage based on legal factors is still less effective.

Less effective legal factors can be assessed as a form of interference from law enforcement and law, which results in several causes, including: ${ }^{15}$

1. Lack of compliance with legal principles;

2. There are still no specific application rules regarding the application of the rule of law;

3. The meaning of words that are not clear in the Law and Regulation causes misunderstanding in interpretation and implementation.

On the other hand, the implementation of post-divorce matrimonial property distribution in a case study of polygamy marriage has been regulated in Article 94 Inpres No. 1 of 1991; Article 65 Law No. 16 of 2019; even more specifically p. 7.

${ }^{14}$ Soekanto, Soerjono. (1985). Efektivikasi Hukum dan Peranan Sanksi. Jakarta: PT. Remaja Rosdakarya,

${ }^{15}$ Soekanto, Soerjono. (2016). Op. Cit., pp. 17 - 18. 
regulated in Decree of the Supreme Court of the Republic of Indonesia Number: $\mathrm{KMA} / 032 / \mathrm{SK} / \mathrm{IV} / 2006$. However, based on the nature of a Decree is clearly different from the nature of the Legislation.

\section{B. Law Enforcement Factors}

The results of the data obtained from the interview process with respondents about the effectiveness of post-divorce matrimonial property distribution in a case study of polygamy marriage based on law enforcement factors can be seen in the table below.

Table 2. Effect of Law Enforcement Factors

\begin{tabular}{c|l|c|c}
\hline \hline No. & Statement/Category & Frequency & Percentage \\
\hline \hline 1. & Effective & 21 & $26,25 \%$ \\
\hline 2. & Less Effective & 58 & $72,50 \%$ \\
\hline 3. & Ineffective & 1 & $1,25 \%$ \\
\hline \hline \multicolumn{2}{r|}{ Total } & $\mathbf{8 0}$ & $\mathbf{1 0 0 \%}$ \\
\hline \hline
\end{tabular}

Source: Questionnaire Results of 2019 - 2020

From the table above it can be seen that there are 21 respondents or $26,25 \%$ claims effective, 58 respondents or 72,50\% claims less effective, and 1 respondents or $1,25 \%$ claim ineffective. It can be judged that the effectiveness of post-divorce matrimonial property distribution in a case study of polygamy marriage based on law enforcement factors is still less effective.

As for the less effective of law enforcement factors, it can be judged that law enforcement does not only apply the legislation or the judge's decision. But in this case, the main problem in law enforcement is found in the factors that influence it openly or not. These factors have a neutral understanding so they can bring positive (good) or negative (bad) effects. Law enforcement factors basically can create conditions where legal norms can function properly. Furthermore, law enforcement must not act arbitrarily in carrying out their duties, they must also pay attention to ethics that apply in the scope of their profession. Law enforcement can be interpreted that: ${ }^{16}$

"A process to make legal wishes come true. The so-called legal desire here is none other than the thinking of legislation-making institutions formulated in the legislation. The formulation of the thinking of legislation makers will also determine the implementation of law enforcement."

Law enforcement in principle is to realize inspiration or theories about justice, truth, social benefits, and so on. So law enforcement is the act of turning inspiration or theory into reality. ${ }^{17}$

${ }^{16}$ Jainah, Zainab Ompu. (2012). Penegakan Hukum dalam Masyarakat. Journal of Rural and Development, Universitas Sebelas Maret, 3(2), p. 165.

${ }^{17}$ Rahardjo, Satjipto. (2010). Masalah Penegakan Hukum: Suatu Tinjauan Sosiologis. Bandung: Sinar Baru, p. 15. 


\section{Facility Factors}

The results of the data obtained from the interview process with respondents about the effectiveness of post-divorce matrimonial property distribution in a case study of polygamy marriage based on facility factors can be seen in the table below.

Table 3. Effect of Facility Factors

\begin{tabular}{c|l|c|c}
\hline \hline No. & Statement/Category & Frequency & Percentage \\
\hline \hline 1. & Effective & 31 & $38,75 \%$ \\
\hline 2. & Less Effective & 48 & $60,00 \%$ \\
\hline 3. & Ineffective & 1 & $1,25 \%$ \\
\hline \hline \multicolumn{2}{c|}{ Total } & $\mathbf{8 0}$ & $\mathbf{1 0 0 \%}$ \\
\hline \hline
\end{tabular}

Source: Questionnaire Results of 2019 - 2020

From the table above it can be seen that there are 31 respondents or $38,75 \%$ claims effective, 48 respondents or $60,00 \%$ claims less effective, and 1 respondents or $1,25 \%$ claim ineffective. It can be judged that the effectiveness of post-divorce matrimonial property distribution in a case study of polygamy marriage based on facility factors is still less effective.

It must be understood together that the means or supporting facilities in the effectiveness of achievement is one of the main factors, as according to Soerjono Soekanto that: ${ }^{18}$

"Without certain facilities, law enforcement will not be carried out properly. These facilities include educated and skilled human resources, good organization, adequate equipment, adequate finance, and so on. If these things are not met, then law enforcement will not achieve its objectives."

\section{Community Factors}

The results of the data obtained from the interview process with respondents about the effectiveness of post-divorce matrimonial property distribution in a case study of polygamy marriage based on community factors can be seen in the table below.

Table 4. Effect of Community Factors

\begin{tabular}{c|l|c|c}
\hline \hline No. & Statement/Category & Frequency & Percentage \\
\hline \hline 1. & Effective & 28 & $35,00 \%$ \\
\hline 2. & Less Effective & 49 & $61,25 \%$ \\
\hline 3. & Ineffective & 3 & $3,75 \%$ \\
\hline \hline \multicolumn{2}{c|}{ Total } & $\mathbf{8 0}$ & $\mathbf{1 0 0 \%}$ \\
\hline \hline
\end{tabular}

Source: Questionnaire Results of 2019 - 2020

From the table above it can be seen that there are 28 respondents or $35,00 \%$ claims effective, 49 respondents or $61,25 \%$ claims less effective, and 3 respondents or $3,75 \%$ claims ineffective. It can be judged that the effectiveness of post-divorce

${ }^{18}$ Soekanto, Soerjono. (2016). Op. Cit., p. 37. 
matrimonial property distribution in a case study of polygamy marriage based on community factors is still less effective.

Less effective community factors can be assessed from the community's unconscious or non-compliance with laws and regulations. In this case no matter how good the legislation, the regulation is still less effective if it is not supported by awareness and legal compliance of citizens. ${ }^{19}$ Furthermore, Soerjono Soekanto stated that: ${ }^{20}$

"Law enforcement comes from the community, so it aims to achieve peace in the community. Therefore, from a certain angle, society can influence law enforcement."

Community awareness and compliance are very important factors, therefore: ${ }^{21}$

"The formation of a new law will become a reality if it is supported by the existence of legal awareness from all members of the community itself. Awareness of the application of the law is the basis for applying the law."

\section{E. Cultural Factors}

The results of the data obtained from the interview process with respondents about the effectiveness of post-divorce matrimonial property distribution in a case study of polygamy marriage based on cultural factors can be seen in the table below.

Table 5. Effect of Cultural Factors

\begin{tabular}{c|l|c|c}
\hline \hline No. & Statement/Category & Frequency & Percentage \\
\hline \hline 1. & Effective & 25 & $31,25 \%$ \\
\hline 2. & Less Effective & 50 & $62,50 \%$ \\
\hline 3. & Ineffective & 5 & $6,25 \%$ \\
\hline \hline \multicolumn{2}{r|}{ Total } & $\mathbf{8 0}$ & $\mathbf{1 0 0 \%}$ \\
\hline \hline
\end{tabular}

Source: Questionnaire Results of 2019 - 2020

From the table above it can be seen that there are 25 respondents or $31,25 \%$ claims effective, 50 respondents or $62,50 \%$ claims less effective, and 5 respondents or $6,25 \%$ claims ineffective. It can be judged that the effectiveness of post-divorce matrimonial property distribution in a case study of polygamy marriage based on cultural factors is still less effective.

Less effective cultural factors can be judged by people's misinterpretations in assessing the relationship between positive law and the norms of indigenous peoples. The norms of indigenous peoples have a universal nature and live in local communities. Characteristics of indigenous peoples include: ${ }^{22}$

\footnotetext{
${ }^{19}$ Hutabarat, Ramly. (1985). Persamaan di Hadapan Hukum (Equality Before the Law) di Indonesia. Jakarta: Ghalia Indonesia, p. 78.

${ }^{20}$ Soekanto, Soerjono. (2016). Op. Cit., p. 45.

${ }^{21}$ Rosana, Ellya. (2014). Kepatuhan Hukum sebagai Wujud Kesadaran Hukum Masyarakat. Jurnal Tapis: Jurnal Teropong Aspirasi Politik Islam, Universitas Islam Negeri Raden Intan Lampung, 10(1), p. 69.

${ }^{22}$ Setiadi, Elly M., Hakam, Kama A., \& Effendi, Ridwan. (2011). Ilmu Sosial dan Budaya Dasar. Jakarta: Kencana Prenada Media Group, pp. 33 - 34.
} 
1. Culture is born and emerges from human action, and is transformed through human action itself;

2. Culture existed before a certain generation, and will not disappear even if that generation has run out;

3. Culture is a necessity for humans, and serves as a guide for their lives; and

4. Culture includes rules that manifest in the form of obligations, including which actions are appropriate and which are not appropriate, and about whether an action can be done or not.

Based on the description of the nature of culture above, the exact articulation of the provisions in the legislation article is necessary given that the nature of culture is the spirit of the legislation itself so that with the articulation of the right rules in society, the legislation can be implemented effectively. As Soerjono Soekanto said that: ${ }^{23}$

"The norms of indigenous peoples are the basis of culture. The norm of indigenous peoples is the law that applies in the midst of the community. In addition, written law (legislation) also applies in societies where it has official power and authority. Legislation must reflect the norm values of indigenous peoples so that the law can be effective."

\section{CONCLUSION}

From the description of the results and discussion above, the effectiveness of postdivorce matrimonial property distribution in a case study of polygamy marriage in the Religious Courts of Class 1A Makassar can be seen based on five factors, including legal factors, law enforcement factors, facility factors, community factors, and cultural factors. Data obtained from all factors showed less effective results, including there, were $65 \%$ claims to legal factors, $72.5 \%$ claims to law enforcement factors, $60 \%$ claims to facility factors, $61.25 \%$ claims to community factors, and $62.5 \%$ claims to cultural factors. Seriousness is needed, especially for law enforcement in carrying out their role, and it is hoped that all relevant stakeholders must socialize the rules regarding procedures for the post-divorce matrimonial property distribution.

\section{REFERENCE}

Abbas, Irwan. (2013). Pappaseng: Kearifan Lokal Manusia Bugis yang Terlupakan. Sosiohumaniora: Jurnal Ilmu-Ilmu Sosial dan Humaniora, Universitas Padjadjaran, 15(3), pp. 272 - 284. doi: https://doi.org/10.24198/sosiohumaniora.v15i3.5752

Alaidrus, Mochammad Soleh. (2009). Pelaksanaan Pembagian Harta Perkawinan dalam Perkawinan Poligami (Studi di Pengadilan Agama Bekasi). Notarius, Universitas Diponegoro, $1(1)$, pp. 1 - 18.

Alexander, Ongky. (2019). Efektivitas Pembagian Harta Gono - Gini Pasca Perceraian dalam Persfektif Yuridis Sosiologis. El-Ghiroh: Jurnal Studi Keislaman, Sekolah Tinggi Agama Islam Bumi Silampari, 16(1), pp. 113 - 129. doi: https://doi. org/10.37092/el-ghiroh.v16i01.70

${ }^{23}$ Soekanto, Soerjono. (2016). Op. Cit., pp. $64-65$. 
Amiruddin, Amiruddin, et al. (2018). The Disputes Settlement of Land Rights between Kajang Tribal Communities and PT. PP London Sumatera Indonesia in Bulukumba. In International Conference on Industrial Technology for Sustainable Development (ICon-ITSD) 2017. IOP Conference Series: Earth and Environmental Science, 175, pp. 1 - 6. doi: https://doi.org/10.1088/1755$1315 / 175 / 1 / 012125$

As-Sanan, Arij Abdurrahman. (2003). Memahami Keadilan dalam Poligami (Ahmad Sahal Hasan, Trans.). Jakarta: PT. Globalmedia Cipta Publishing.

Badewi, Muhamad Hadis. (2019). Nilai Siri' dan Pesse dalam Kebudayaan BugisMakassar, dan Relevansinya terhadap Penguatan Nilai Kebangsaan. JSW (Jurnal Sosiologi Walisongo), Universitas Islam Negeri Walisongo Semarang, 3(1), pp. 79 - 96. doi: http://dx.doi.org/10.21580/jsw.2019.3.1.3291

Bahtiar, Bahtiar. (2019). Hubungan Politik Antar Kerajaan: Gowa Dengan Bone, Soppeng, Wajo (Tellumpocco). Walasuji: Jurnal Sejarah dan Budaya, Balai Pelestarian Nilai Budaya Makassar, 10(2), pp. 251 - 267. doi: https://doi.org/10.36869/wjsb. v10i2.12

Begem, Sarah Sarmila, Qamar, Nurul, \& Baharuddin, Hamza. (2019). Sistem Hukum Penyelesaian Pelanggaran Hak Asasi Manusia (HAM) Berat Melalui Mahkamah Pidana Internasional. SIGn Jurnal Hukum, CV. Social Politic Genius (SIGn), 1(1), pp. 1 - 17. doi: https://doi.org/10.37276/sjh.v1i1.28

Dahwal, Sirman. (2017). Perbandingan Hukum Perkawinan. Bandung: CV. Mandar Maju.

Farid, A. Zainal Abidin. (1983). Persepsi Orang Bugis Makassar tentang Hukum, Negara dan Dunia Luar. Bandung: PT. Alumni.

Farid, A. Zainal Abidin. (2017). Capita Selecta: Kebudayaan Sulawesi Selatan. Makassar: CV. Social Politic Genius (SIGn).

Farid, A. Zainal Abidin. (2017). Capita Selecta: Sejarah Sulawesi Selatan. Makassar: CV. Social Politic Genius (SIGn).

Fitrianti, Desi. (2017). Harta Bersama dalam Perkawinan Poligami Menurut UndangUndang Nomor 1 Tahun 1974 dan Hukum Islam. Jurnal Intelektualita: Keislaman, Sosial dan Sains, Universitas Islam Negeri Raden Fatah Palembang, 6(1), pp. 83 102. doi: https://doi.org/10.19109/intelektualita.v6i1.1302

Friedman, Lawrence M. (2008). Sistem Hukum: Perspektif Ilmu Sosial (M. Khozim, Trans.). Bandung: Nusa Media.

Government Regulation of the Republic of Indonesia Number 9 of 1975 on the Implementation of Law Number 1 of 1974 on Marriage. (State Gazette of the Republic of Indonesia of 1975 Number 12, Supplement to the State Gazette of the Republic of Indonesia Number 3050).

Haar, Barend ter. (2011). Asas-Asas dan Susunan Hukum Adat (Freddy Tengker, Trans.). Bandung: CV. Mandar Maju. 
Hadi, Syofyan. (2017). Hukum Positif dan The Living Law (Eksistensi dan Keberlakuannya dalam Masyarakat). DIH: Jurnal Ilmu Hukum, Universitas 17 Agustus 1945 Surabaya, 13(26), pp. 259 - 266. doi: https://doi.org/10.30996/ dih.v0i0.1588

Hasan, M. Ali. (2003). Pedoman Hidup Berumah Tangga dalam Islam. Jakarta: Kencana Prenada Media Group.

Hazairin. (1974). Tujuh Serangkai Tentang Hukum. Jakarta: Tintamas.

Husen, La Ode \& Thamrin, Husni. (2017). Hukum Konstitusi: Kesepakatan (Agreement) dan Kebiasaan (Custom) Sebagai Pilar Konvensi Ketatanegaraan. Makassar: CV. Social Politic Genius (SIGn).

Husen, La Ode. (2019). Negara Hukum, Demokrasi dan Pemisahan Kekuasaan. Makassar: CV. Social Politic Genius (SIGn).

Hutabarat, Ramly. (1985). Persamaan di Hadapan Hukum (Equality Before the Law) di Indonesia. Jakarta: Ghalia Indonesia.

Ja'far, Ahmad Khumaidi. (2012). Teori-Teori Pemberlakuan Hukum Islam di Indonesia. Asas, Universitas Islam Negeri Raden Intan Lampung, 4(2), pp. 1 - 6.

Jainah, Zainab Ompu. (2012). Penegakan Hukum dalam Masyarakat. Journal of Rural and Development, Universitas Sebelas Maret, 3(2), pp. 165 - 172.

Kern, R. A. (1989). I La Galigo: Cerita Bugis (La Side \& Sagimun Mulus Dumadi, Trans.). Yogyakarta: UGM Press.

Law of the Republic of Indonesia Number 1 of 1974 on Marriage. (State Gazette of the Republic of Indonesia of 1974 Number 1, Supplement to the State Gazette of the Republic of Indonesia Number 3019).

Law of the Republic of Indonesia Number 12 of 2011 on Legislation Making. (State Gazette of the Republic of Indonesia of 2011 Number 82, Supplement to the State Gazette of the Republic of Indonesia Number 5234).

Law of the Republic of Indonesia Number 16 of 2019 on Amendment to Law Number 1 of 1974 on Marriage. (State Gazette of the Republic of Indonesia of 2019 Number 186, Supplement to the State Gazette of the Republic of Indonesia Number 6401).

Mattulada. (1998). Sejarah, Masyarakat, dan Kebudayaan Sulawesi Selatan. Ujung Pandang: Hasanuddin University Press.

Presidential Instruction of the Republic of Indonesia Number 1 of 1991 on Spread of Compilation of Islamic Law.

Qamar, Nurul, et al. (2018). Menguak Nilai Kearifan Lokal Bugis Makassar: Perspektif Hukum dan Pemerintahan. Makassar: CV. Social Politic Genius (SIGn).

Rahardjo, Satjipto. (2010). Masalah Penegakan Hukum: Suatu Tinjauan Sosiologis. Bandung: Sinar Baru.

Rahim, A. Rahman. (1992). Nilai-Nilai Utama Kebudayaan Bugis. Ujung Pandang: Hasanuddin University Press. 
Rahman, Sufirman, Qamar, Nurul, \& Amiruddin, Amiruddin. (2018). Resolution of Land Rights Conflict Resolution of Customary Law Community at Foreign Investments Company. In $2^{\text {nd }}$ International Conference on Statistics, Mathematics, Teaching, and Research. Journal of Physics: Conference Series, 1028, pp. 1 - 6. doi: https:// doi.org/10.1088/1742-6596/1028/1/012179

Rahman, Sufirman, Qamar, Nurul, \& Kamran, Muhammad. (2020). Efektivitas Pembagian Harta Bersama Pasca Perceraian: Studi Kasus Perkawinan Poligami. SIGn Jurnal Hukum, CV. Social Politic Genius (SIGn), 1(2), pp. 104 - 118. doi: https://doi.org/10.37276/sjh.v1i2.60

Rosana, Ellya. (2014). Kepatuhan Hukum sebagai Wujud Kesadaran Hukum Masyarakat. Jurnal Tapis: Jurnal Teropong Aspirasi Politik Islam, Universitas Islam Negeri Raden Intan Lampung, 10(1), pp. 61 - 84. doi: https://doi.org/10.24042/ tps.v10i1.1600

S., Salim H. \& Nurbani, Erlies Septiana. (2013). Penerapan Teori Hukum pada Penelitian Tesis dan Disertasi. Jakarta: PT. Raja Grafindo Persada.

Sampara, Said \& Husen, La Ode. (2016). Metodologi Penelitian Hukum. Makassar: Kretakupa Print.

Setiadi, Elly M., Hakam, Kama A., \& Effendi, Ridwan. (2011). Ilmu Sosial dan Budaya Dasar. Jakarta: Kencana Prenada Media Group.

Siregar, Nur Fitryani. (2018). Efektivitas Hukum. Al-Razi: Jurnal Ilmu Pengetahuan dan Kemasyarakatan, Sekolah Tinggi Agama Islam Barumun Raya, 18(2), pp. 1 - 16.

Soekanto, Soerjono, Hendratno, Edie T., \& Sardjito, T. H. (1984). Antropologi Hukum: Proses Pengembangan Ilmu Hukum Adat. Jakarta: Rajawali Pers.

Soekanto, Soerjono. (1985). Efektivikasi Hukum dan Peranan Sanksi. Jakarta: PT. Remaja Rosdakarya.

Soekanto, Soerjono. (1987). Hubungan Hukum Adat dengan Hukum Islam. Jurnal Hukum \& Pembangunan, Universitas Indonesia, 17(2), pp. 152 - 162. doi: http:// dx.doi.org/10.21143/jhp.vol17.no2.1300

Soekanto, Soerjono. (2016). Faktor-Faktor yang Mempengaruhi Penegakan Hukum. Jakarta: PT. Raja Grafindo Persada.

Soepomo, R. (1970). Hubungan Individu dan Masyarakat dalam Hukum Adat. Jakarta: PT. Pradnya Paramita.

Thalib, Sayuti. (1980). Receptio A Contrario: Hubungan Hukum Adat dengan Hukum Islam. Jakarta: PT. Bina Aksara.

Vollenhoven, Cornelis van. (1934). Staatsrecht Overzee. Laiden: Stenfert Kroese.

Yunus, Ahyuni. (2020). Hukum Perkawinan dan Itsbat Nikah: Antara Perlindungan dan Kepastian Hukum. Makassar: Humanities Genius.

Yusuf, Muhammad. (2013). Relevansi Nilai-Nilai Budaya Bugis dan Pemikiran Ulama Bugis: Studi atas Pemikirannya dalam Tafsir Berbahasa Bugis Karya MUI Sulsel. El-Harakah: Jurnal Budaya Islam, Universitas Islam Negeri Maulana Malik Ibrahim, 15(2), pp. 199 - 216. doi: http://dx.doi.org/10.18860/el.v15i2.2766 
Zunaidi, Arif. (2018). Kedudukan Harta Bersama Perkawinan Poligami. Mahakim: Journal of Islamic Family Law, Institut Agama Islam Negeri Kediri, 2(2), pp. 91 106. doi: http://dx.doi.org/10.30762/mh.v2i2.975

\footnotetext{
I Kamran, Muhammad. (2020). Post-Divorce Matrimonial Property Distribution: A Case I I Study of Polygamy Marriage. Sovereign: International Journal of Law, CV. Social Politic I I Genius (SIGn), 2(2), pp. 13 - 26. doi: https://doi.org/10.37276/sijl.v2i2.29
} 